\title{
Introduction: Port State Jurisdiction: Challenges and Potential
}

\author{
Cedric Ryngaert*
}

Professor of Public International Law, School of Law, Utrecht University, Utrecht, The Netherlands

\section{Henrik Ringbom}

Professor II, Scandinavian Institute of Maritime Law, Faculty of Law, University of Oslo, Oslo, Norway; Adjunct Professor (Docent) Department of Law, Åbo Akademi University, Turku/Åbo, Finland

\begin{abstract}
Confronted with the failures of flag states to adequately regulate their vessels, and/or to enforce applicable law, port states may assume a subsidiary regulatory and enforcement role. Exercising port state jurisdiction (PSJ) over foreign-flagged vessels, these port states may give effect to generally applicable international rules and standards, or simply apply their own laws. As the exercise of PSJ over foreign-flagged vessels often has effects outside the port, or even aims to regulate activities beyond national jurisdiction, legitimate questions as to the territorial nature of PSJ can be asked. It transpires, however, that most assertions of PSJ can formally be justified under a broad construction of the territoriality principle. Alternatively, they can find their basis in multilateral agreements or simply in the desire to protect common concerns. As the legality net regarding PSJ could thus be cast rather wide, the question, i.e., to what limitations such jurisdiction is subject, inevitably arises.
\end{abstract}

* Cedric Ryngaert acknowledges the financial support of the European Research Council under the Starting Grant Scheme (Proposal 336230-UNIJURIS) and the Dutch Organization for Scientific Research under the VIDI Scheme (No 016.135.322).

(C) CEDRIC RYNGAERT AND HENRIK RINGBOM, 2016 | DOI 10.1163/15718085-12341405

This is an open access article distributed under the terms of the Creative Commons Attribution 4.0

Unported (CC-BY-NC 4.o) License. http://creativecommons.org/liçenses/by-ncł4.o/ Brill.com๑4/26/2023 01:16:44PM 


\section{Keywords}

port State jurisdiction (PSJ) - unilateralism - principle of territoriality - interest power-common concern

\section{Introduction}

Confronted with the failures of flag states to adequately regulate their vessels, and/or to enforce applicable law, port states - the states at whose ports these vessels call-may assume a subsidiary regulatory and enforcement role. Exercising port state jurisdiction (PSJ) over foreign-flagged vessels, these port states may give effect to generally applicable international rules and standards, or simply apply their own laws. This special issue takes stock of, and assesses the extant practice of PSJ, its (legal) limits and its untapped potential. It bundles six contributions, largely structured along thematic lines: ${ }^{1}(1)$ the exercise of PSJ over shipping activities (including construction, design, equipment, and manning (CDEM) standards, pollution, and information requirements); (2) the use of PSJ to clamp down on illegal, unregulated and unsustainable (IUU) fishing activities; and (3) the regulation and enforcement of labour standards on board vessels calling at a port. One contribution addresses the more general relationship between the principle of exclusive flag state jurisdiction (FSJ) and PSJ that has relevance for all PSJ assertions, regardless of the nature of the regulated activity.

The purpose of this introductory article by the special issue's editors is to set the stage and identify up front a number of cross-cutting issues that are developed at greater length in the contributions to follow. We start in the first section, by parsing the jurisdictional nature of PSJ: is such jurisdiction territorial or extra-territorial? This question is not just a theoretical one; whether a jurisdictional assertion is territorial is an important threshold question which in the traditional international law of jurisdiction yields its presumptive lawfulness. As the exercise of PSJ over foreign-flagged vessels often has effects outside the port, or even aims to regulate activities beyond national jurisdiction, legitimate questions as to the territorial nature of PSJ can be asked. It transpires from the contributions to this special issue that most assertions of PSJ can formally be justified under a broad construction of the territoriality

1 Draft papers were presented at a conference organized at Utrecht University on 14 December 2015. The editors thank the European Research Council and the Dutch Organization for Scientific Research for funding this conference. 
principle, or somewhat less frequently on the basis of multilateral agreements providing for PSJ.

As the legality net regarding PSJ is cast rather wide, the question inevitably arises of to what limitations such jurisdiction is subject. The second section argues that few limitations could be drawn from the UN Convention on the Law of the Sea (LOSC) itself, which hardly addresses PSJ. The main limitations to PSJ probably come from international trade law and general principles of jurisdiction. Such limitations should inform PSJ practice, and may, as the third section discusses, also guide adjudicatory practice. The last section finally enquires into what drives port states to exercise PSJ. It is argued that a desire to protect and promote national economic (or at times environmental) interests, often related to the safeguarding of competitive opportunities for national businesses subject to strict environmental and labour regulation, will normally underlie assertions of PSJ. However, such interest-based assertions should not readily be dismissed as myopic or self-serving, as they may have beneficial effects on common interests or concerns, such as sustainable fishing, the protection of the marine environment, or labour rights. Arguably, the common interest or concern could serve, in itself, as a justification for assertions of PSJ, insofar as these are genuinely devised to protect a common, rather than a purely national, interest or concern. If this argument proves convincing, it may well embolden the exercise of PSJ.

\section{The Nature of Port State Jurisdiction: Territoriality versus Extra-territoriality}

In jurisdictional discourse, there may be a tendency to consider jurisdictional assertions that are based on territory as presumptively valid and legitimate, and those that are extra-territorial in nature as suspect and even illegitimate. 'Territoriality' and 'extra-territoriality' are, however, just container terms that are semantically unstable. What one protagonist considers territorial, another protagonist with different underlying interests might consider as extra-territorial. ${ }^{2}$ Nevertheless, territoriality has proved to be an enduring cognitive script throughout the law of jurisdiction and international law generally. PSJ is not very different in this respect. Defenders of PSJ are quick to point out that such jurisdiction is, for all intents and purposes, territorial, even if it may take into account circumstances or produce effects outside the territory.

2 HL Buxbaum, 'Territory, Territoriality, and the Resolution of Jurisdictional Conflict' (2009) 57 American Journal of Comparative Law 631-675, at p. 635 . 
The main argument is that ports are part of a state's territory, and thus, that port states have the right to deny entry to visiting vessels, and hence, a fortiori, to place conditions for such access, to carry out inspections and possibly institute proceedings against visiting vessels suspected of breaches. Foreignflagged vessels indeed have no right of entry into port (unless specific international law obligations provide otherwise), and in port they need to comply with port state law, just like any foreign person needs to comply with the law of the visited territory. And precisely because a state exercises territorial sovereignty over its ports, port states have residual territorial jurisdiction under customary international law, which entails that international law allows port states to take more stringent measures than provided in international agreements, unless the agreements specifically rule out such additional measures, which is normally not the case. In fact, international agreements have increasingly affirmed the existence of such residual jurisdiction; notably international agreements on fishing, both binding and non-binding, have emphasized port states' right to exercise jurisdiction over visiting vessels in rather explicit terms. ${ }^{3}$

While it is intuitive to state that port state jurisdiction is territorial, analytically speaking one needs to carefully distinguish between port state prescriptive jurisdiction and port state enforcement jurisdiction. This distinction sometimes appears to be insufficiently made in the discussion on PSJ. Logically, the exercise of PSJ is an instance of territorial enforcement jurisdiction, as by definition the port state enforces its measures within the territorially delimited port. ${ }^{4}$ It is equally logical, however, that the scope of a state's (territorial) enforcement

3 E.g., International Plan of Action to Prevent, Deter, and Eliminate Illegal, Unreported and Unregulated Fishing, para. 58, available at http://www.fao.org/fishery/ipoa-iuu/en, accessed 23 June 2016; Preamble of the Agreement on Port State Measures to Prevent, Deter and Eliminate Illegal, Unreported and Unregulated Fishing (Rome, 22 November 2009, in force 5 June 2016, Appendix v, FAO Council, 137th Session, Rome, 28 September-2 October 2009) ("Bearing in mind that, in the exercise of their sovereignty over ports located in their territory, States may adopt more stringent measures, in accordance with international law"). Article 1(3) of the International Convention on the Control of Harmful Anti-fouling Systems on Ships (London, 5 October 2001, in force 17 September 2008, IMo Doc. AFs/Conf/26 (5 October 2001) similarly provides that "[n]o provision of this Convention shall be interpreted as preventing a State from taking, individually or jointly, more stringent measures with respect to the reduction or elimination of adverse effects of anti-fouling systems on the environment, consistent with international law".

4 Denial of entry to a port, which is increasingly used as an enforcement tool in shipping, could also be considered as an exercise of territorial enforcement jurisdiction, or at least an exercise of state authority linked to its exclusive territorial sovereignty over the port. 
jurisdiction cannot be wider than the scope of its prescriptive jurisdiction. Put differently, a state can only enforce norms which it had the authority to prescribe in the first place. Accordingly, the focus of the inquiry should shift to the boundaries of a port state's prescriptive jurisdiction.

In the common understanding of territoriality for prescriptive jurisdiction purposes, a state has jurisdiction over acts that occur, at least in part, in its territory. As a result, there is little doubt that port states have jurisdiction over activities within the port itself. As Robin Churchill argues, this even extends to CDEM standards, as a failure to comply with such standards may well threaten the safety of shipping and the environment in the state's ports. Given the static nature of such standards, such assertions of territorial jurisdiction will almost as a matter of course produce extra-territorial effects, but this need not detract from their principled legality (although perhaps from their desirability). Territoriality, even in its extended version, ${ }^{5}$ will however not normally assist in the justification of assertions of prescriptive jurisdiction over activities that bear no relation to a state's territory. Admittedly, such assertions could still be justified on the basis of functional, 'quasi-territorial, ${ }^{6}$ prescriptive jurisdiction insofar as port states also double as coastal states which have, in accordance with the LOsC, jurisdictional powers over certain activities within their maritime zones (territorial sea, contiguous zone, exclusive economic zone [EEZ]). ${ }^{7}$ However, to the extent that PSJ pertains to activities occurring entirely outside areas within national jurisdiction (the high seas or other states' coastal waters), territoriality cannot be the basis of jurisdiction and its exercise will need to rely on other potential jurisdictional bases to be lawful.

International agreements could offer a legal basis for such 'extraterritorial' jurisdiction. Thus, Article 218 LOSC provides for PSJ "in respect of any discharge from that vessel outside the internal waters, territorial sea or exclusive economic zone of that State in violation of applicable international rules and

5 See more generally on territorial extension, especially of European Union (EU) law: J Scott, 'Extraterritoriality and Territorial Extension in EU Law' (2014) 62(1) American Journal of Comparative Law $87-125$.

6 See EJ Molenaar, 'Options for Regional Regulation of Merchant Shipping Outside Imo, with Particular Reference to the Arctic Region' (2014) 45(3) Ocean Development and International Law 272-298, at pp. 228-229.

7 Note that a coastal state's enforcement jurisdiction in its maritime zones is relatively limited (cf. Articles 27 and 33 United Nations Convention on the Law of the Sea (Montego Bay, 10 December 1982, in force 16 November 1994) (LOSC) 1833 UNTS 3, with respect to the territorial sea and the contiguous zone; but see Article 111 on the right to hot pursuit). Thus, PSJ may offer important benefits in terms of enforcing compliance with laws in a coastal state's maritime zones. 
standards established through the competent international organization or general diplomatic conference". Although the LOSC does not feature similar provisions for other types of violations, other agreements do. As Judith Swan has demonstrated, this is the case most notably as regards fisheries, where the urgency of tackling the problem of IUU fishing through PSJ is most acutely felt. In addition, port states have found ingenious ways to territorialize extraterritorial offenses, without—somewhat surprisingly perhaps-meeting sizable protest: ${ }^{8}$ jurisdiction is then premised, for example, on the failure to produce an accurate oil record book upon entry into port (to tackle pollution), or false declarations regarding the introduction in port of harvested fish (to tackled IUU fishing), or, as Bevan Marten has argued at length in this issue, the failure to collect information when reporting to the port state (in respect of fishing, safety, pollution, etc.). ${ }^{9}$ Given the potential for territorialisation, many assertions of what are, on closer inspection, extra-territorial violations could eventually be justified under the territoriality principle. This, in turn, raises the question of whether territoriality still serves its function as a principle of jurisdictional order. ${ }^{10}$

The artificiality of territoriality has caused some to theorize international functional jurisdiction in PSJ; it has been proposed, for example, that states are allowed to resort to PSJ only to the extent that they vindicate common interests of the parties to the LOSC (such as the protection of the marine environment). Accordingly, states can exercise PSJ when this promotes the basic functions of the international regime of the law of the sea. ${ }^{11}$ A similar argument has been made by Sophia Kopela, who considers "the concept of global commons as an issue of common concern" as a legitimate and reasonable jurisdictional link. ${ }^{12}$ These approaches depart from the classical connection-based operation of the law of jurisdiction, and call for the incorporation of substantive values

8 S Kopela, 'Port State Jurisdiction, Extraterritoriality and the Protection of Global Commons (2016) 47(2) Ocean Development and International Law 89-130, at p. 97.

9 Bevan argues in his contribution to this special issue that such regulatory tools do not raise extra-territoriality concerns. Territorialization is also how the EU's MRV Regulation could potentially be justified: the territorial connection is constituted by the foreign vessel's failure to report in port on emissions outside the EU Member States' relevant maritime zones.

10 See more in general C Ryngaert, 'Whither Territoriality? The European Union's Use of Territoriality to Set Norms with Universal Effects', in C Ryngaert, EJ Molenaar and SMH Nouwen (eds), What's Wrong with International Law (Brill, Leiden, 2015) 434-448.

11 This question is explored in more detail in the forthcoming Ph.D. thesis by Nelson Coelho, another member of the UNIJURIS research team at the University of Utrecht. 
and functions into the jurisdictional analysis. They can be credited for being in sync, much more than classic territoriality, with current borderless/global challenges, and may embolden port states to take more action in relation to common concerns.

Finally, a port state's jurisdiction to regulate foreign ships may depend on the choice of measure to enforce the requirements. As Erik Molenaar has argued, a distinction should be made between enforcement measures of a punitive character (such as fines, arrest of the ship, etc.) and those that merely withhold benefits to which foreign ships are not entitled under international law. ${ }^{13}$ Because access to ports belongs to the latter category, it is easier to find a jurisdictional basis for requirements that are implemented only by means of denial of (future) port access than for requirements where non-compliance results in sanctions and/or legal proceedings. This is a paradox, because denial of access, in particular when implemented collectively by several states, as is commonly done within the European Union (EU), ${ }^{14}$ will usually represent a bigger intrusion on ships' possibilities to trade and navigate than a monetary penalty.

Still, irrespective of how PSJ is precisely justified-pursuant to territoriality, multilateral agreements, the notion of common concern or port access conditions - the next question is whether there are any international law limits to the exercise of PSJ. The justificatory discourses used may indeed offer support to a rather wide range of PSJ assertions with little heed being paid to countervailing considerations, such as the interests of the flag states and the owners of the targeted vessels.

\section{Limitations of Port State Jurisdiction}

As stated already above, PSJ developed as a form of subsidiary jurisdiction to remedy the deficiencies of FSJ, especially the regulatory and enforcement vacuum left by flags of convenience. In spite of the understandable policy considerations on which the shift from FSJ to PSJ rests, the normative relationship between the two forms of jurisdiction has remained somewhat unclear, however. This has opened the door for the argument that FSJ, in combination with the freedom of the high seas and the fact that the LOSC largely remains silent about PSJ, actually limit PSJ. Typically, Article 92(1) LOSC is cited in this

\footnotetext{
13 EJ Molenaar, 'Port State Jurisdiction: Toward Comprehensive, Mandatory and Global Coverage' (2007) 38 Ocean Development and International Law 225-257, at p. 229.

14 See in particular, Directive 2009/16/EC of the European Parliament and of the Council of 23 April 2009 on port State control (Recast) [2009] oJ L131/57, Article 16.
} 
respect, a provision that stipulates that "[s]hips shall sail under the flag of one State only and, save in exceptional cases expressly provided for in international treaties or in this Convention, shall be subject to its exclusive jurisdiction on the high seas". The provision does, however, not distinguish between prescriptive and enforcement jurisdiction.

In this issue, Arron Honniball argues, quite convincingly, that Article 92 addresses enforcement jurisdiction on the high seas. Accordingly, it is not relevant for PSJ, which is, as pointed out above, necessarily only enforced in port. In this reading, Article 92 does not limit the reach of a port state's prescriptive jurisdiction. But it does not offer a direct justification for such jurisdiction either. This implies that a flag state can still protest a port state's exercise of jurisdiction on the ground that the latter is overreaching, and that the former retains a stronger connection to or interest in the operation of its vessels. Such an argument may however gradually lose its strength in light of the increasing information-gathering capacities of port states, which, as Bevan Marten argues in this issue, may upset the actual balance of authority between flag states and port states. This means that in due course the flag state, having lost its exclusive authority, if it ever had one, may also lose its primary authority over the vessels flying its flag. If anything, however, such a tendency of incrementally expanding PSJ authority cannot be said to obviate the need to identify limitations, rather the contrary.

It is of note that the LOSC itself, not having been drafted with PSJ in mind, contains few other limitations on the exercise of PSJ. The rule of law-based due publicity regarding the imposition of requirements for the prevention, reduction and control of pollution of the marine environment as a condition for the entry of foreign vessels (Article 211(3) LOSC) can be cited here, as well as the limiting conditions of Article 218 LOSC, which balance the rights of the port state with those of the flag state. In addition, the Losc's express obligation for states to act in good faith and its prohibition on the abuse of rights (Article 300 LOSC) place more general limitations on the regulatory discretion of states, including in the exercise of PSJ.

Yet the most potent limitation to PSJ may actually come from outside the law of the sea, in particular from international trade law, where normcompliance can also be enforced before the dispute-settlement mechanism of the World Trade Organization (WTO). As PSJ may restrict the international trade, especially in goods, it may well run afoul of wTо law (General Agreement on Tariffs and Trade [GATT ${ }^{15}$ ). In their contributions to this issue,

15 General Agreement on Tariffs and Trade (Geneva, 30 October 1947, in force 1 January 1948; 55 UNTS 308.). 
Robin Churchill and Andrew Serdy acknowledge the tension between PSJ and the GATT, ${ }^{16}$ but they consider that even if a breach of a substantive GATT provision were to be found, it could in many circumstances be saved by the public policy exceptions of Article XX GATT, insofar as the relevant PSJ measures, in accordance with the chapeau of this provision, do not serve protectionist purposes, give effect to multilateral agreements, or, if taken unilaterally, have been preceded by an attempt at finding a multilateral solution. Thus, as Serdy argues, IUU fishing could, since the adoption of the FAO Port State Measures Agreement, more easily pass the GATT compatibility test. Similarly, GATT compliance with the EU maritime emissions monitoring, reporting, and verification scheme, which does include certain elements of 'unilateral' port state jurisdiction to be implemented by the EU Member States, ${ }^{17}$ could be based on the scheme giving effect to international agreements on climate change, or on the failure of the International Maritime Organization (IMO) to adequately address maritime emissions despite the Eu's prodding. It is of note that this reasoning somewhat resembles the 'common concern' jurisdictional argument presented above. This is no coincidence, as the common concern may well inform the implicit jurisdictional limitation of GATT Article XX (b) and (g) - the exceptions saving 'extra-territorial' state measures necessary to protect human, animal or plant life or health, or related to the conservation of exhaustible natural resources. ${ }^{18}$

Under the general international law of jurisdiction, it could be argued that the main limitations to PSJ stem from the requirement that there be a

16 PSJ may notably be in tension with GATT Article V (freedom of transition) and Article IX (prohibition of quantitative restrictions on imports).

17 Regulation (EU) 2015/757 of the European Parliament and of the Council of 29 April 2015 on the monitoring, reporting and verification of carbon dioxide emissions from maritime transport, and amending Directive 2009/16/EC [2015] OJ L123/55 (MRV Regulation) gradually introduces obligations for shipowners to plan and to monitor and to report to the $\mathrm{EU}$ their estimated $\mathrm{CO}_{2}$ emissions and includes strong enforcement measures for noncompliers (including — as a measure of last resort — the banning of the ship in question from all EU ports).

18 Arguably, the fact that these measures further a common concern may weaken (although do not obviate) the need for a strong territorial nexus. See also B Cooreman, 'Addressing Environmental Concerns through Trade: A Case for Extraterritoriality?' (2016) 65(1) International and Comparative Law Quarterly 229-248; B Cooreman, 'Addressing Global Environmental Concerns through Trade Measures: Extraterritoriality under WTO Law From a Comparative Perspective' (PhD Thesis, Leiden University, 2016). Chapter vir.3 reviews IUU fishing regulation using this evaluative framework. 
substantial connection between the port state and the regulated subjectmatter, ${ }^{19}$ that the port state not abuse its rights, ${ }^{20}$ and that the port state exercise its jurisdiction reasonably ${ }^{21}$ and that it pay due regard to the interests of affected states and persons. ${ }^{22}$ Given the capaciousness of these concepts, they may not give very concrete guidance regarding the actual exercise of PSJ, and may be open to self-serving interpretations by port states or their contestants. However, in light of the over-inclusiveness of the territoriality principle on which PSJ is traditionally based, an 'informed reasonableness' test, which allows for the balancing of a multitude of interests and connections, may be the only viable jurisdictional limitation to overbroad assertions of PSJ.

\section{Adjudication}

As is often the case in international law, whether states comply with the limits - or obligations - which international law sets regarding the exercise of PSJ, may very much seem to be a question of auto-interpretation by states. As this creates a risk of self-serving compliance assessments, mature legal systems provide for judicial dispute-settlement. As regards PSJ, there may in fact be a rather wide range of dispute-settlement fora available, even if, given the relatively scarcity of PSJ measures and the general lack of contestation of such measures, few judicial proceedings have actually been instituted.

Internationally, PSJ cases pitting (port) states against (flag) states could be brought before the International Court of Justice, a specific law of the sea tribunal (either the International Tribunal for the Law of the Sea or an arbitral tribunal), ${ }^{23}$ or the WTO dispute-settlement mechanism (if the exercise

19 See B Marten, 'Port State Jurisdiction, International Conventions, and Extraterritoriality: An Expansive Interpretation' in H Ringbom (ed), Jurisdiction over Ships: Post-UNCLOS Developments in the Law of the Sea (Brill, Leiden, 2015) 103-139. See also Marten in this special issue (arguing that a port state's imposition of an information request and a corresponding levy relating to matters arising during a vessel's voyage to port may easily be justified under the territoriality principle, but the flag state could more convincingly argue that "the matter in substance pertained to issues on the high seas and was not sufficiently connected with the port state's own interests to be justified").

20 As also laid down in Article 300 LosC.

21 On the rule of reason, see American Law Institute, Restatement (Third) Foreign Relations Law of the United States (1987), at $§ 403$.

22 E Benvenisti, 'Sovereigns as Trustees of Humanity: On the Accountability of States to Foreign Stakeholders' (2013) 107(2) American Journal of International Law 295-333.

23 Article 287 LOSC. 
of PSJ has a trade dimension, which will normally be the case). The (scarce) litigation practice regarding PSJ has showed that judicial proceedings concerning PSJ could be brought, via suit and countersuit, before several fora at the same time. ${ }^{24}$ This raises the questions as to which international forum should prevail in cases of conflicting outcomes and if there is a particular forum that would be best placed for dealing with PSJ matters. It is worth noting that available fora are not limited to supranational ones, as private persons, such as ship-owners, may have standing to contest, in domestic or regional courts, port state measures adversely affecting them. ${ }^{25}$ Private persons may also judicially trigger port state measures by bringing proceedings in domestic courts; this may for instance happen where a non-governmental organization addressing sustainable fishing and/or the marine environment has standing to act in the public interest, and on that basis goes on to sue the state for failing to exercise PSJ. ${ }^{26}$

24 In the Swordfish dispute between the European Community (at the time) and Chile, the Community had launched proceedings before a wTO panel, whereas Chile countersued before itLos, see wTo doc WT/DS193/3 (6 April 2001), "Chile-Measures Affecting the Transit and Importation of Swordfish: Arrangement between the European Communities and Chile". Along the same lines, in the Atlanto-Scandian herring dispute, proceedings were brought both under LOSC and before the wTO. Both disputes were eventually settled, however, see WTO doc WT/DS469/2 (10 January 2014), "European Union-Measures on Atlanto-Scandian Herring: Request for the Establishment of a Panel by Denmark in Respect of the Faroe Islands".

25 E.g., the New Zealand case of Sellers $v$ Maritime Safety Inspector [1999] 2 NZLR 44 (annulling a New Zealand port state measure on the ground that it had an impermissible effect on the high seas). For a different outcome (specifically acknowledging that the port of Helsingborg could impose municipal CDEM requirements on ferries in regular traffic to reduce the emissions of nitrogen oxides in the port), see Miljönämnden i Helsingborgs kommun v. HH Ferries and Sundbusserne, Case No. M 8471-03, Svea Court of Appeal, Environmental Court of Appeal (Miljööverdomstolen), 24 May 2006. Shipowners may also have standing before EU courts to contest EU port state measures, but they may not be able to directly invoke the Losc or wTo law. Cf. generally (the cases do not concern PSJ): The Queen, on the application of International Association of Independent Tanker Owners (Intertanko) and Others v Secretary of State for Transport, Case C-308/06, [2008] ECR I-04057; Portuguese Republic $v$ Council of the European Union, Case C-149/96 [1999] ECR I-8395, at paras 34-46.

26 Compare the Dutch Urgenda case, District Court of The Hague, Judgment of 24 June 2015, ECLI:NL:RBDHA:2015:7145, in which a non-governmental organization (NGO) successfully sued the Dutch Government in a Dutch court for failing to reduce greenhouse gas emissions (the case did not concern PSJ). 
Finally, private persons may sue other private persons before a port state court in relation to activities on a vessel calling at port. This will typically happen in labour disputes, where the vessel's sailors sue the vessel's owner for labour law violations. Such private-to-private disputes are governed by private international law rather than public international law, and raise questions of whether the port state court is the appropriate forum for these disputes, and of whether port state law can/should apply at all. Still, as Laura Carballo demonstrates in her contribution to this special issue, the techniques which private international law uses to ascertain whether a state has adjudicatory jurisdiction over vessels calling at its ports and whether port state law is the applicable law, resemble the public international law techniques used to determine whether the port state has PSJ, in the sense that both legal fields seek to identify a close territorial connection between the subject-matter and the port state, in which case the jurisdiction of the flag state and its law are displaced. Application of the principle of proximity may thus lead to a finding of jurisdiction in the port state and an application of port state law where the worker's habitual place of work, in a wide understanding of the term, is the port, or even, for jurisdictional purposes, where the ship has been detained in port. International maritime law Conventions can be supportive in this regard. Notably, as Carballo points out, the Ship Arrest Convention (1999) provides that "the Courts of the State in which an arrest has been effected or security provided to obtain the release of the ship shall have jurisdiction to determine the case upon its merits". ${ }^{27}$ As far as the applicable law in port state adjudication is concerned, reference can also be made to the Maritime Labour Convention, which sets minimum international standards for maritime labour. ${ }^{28}$ Port state courts may well apply these standards, as overriding mandatory rules or lois de police, in cases where the normally applicable flag state norms are considered to be substandard and insufficiently protective of seafarers' interests. The private law perspective hence appears to support the idea that flag states are not exclusively competent to deal with all matters on board the ship and that even maritime labour law disputes offer some scope

27 International Convention on the Arrest of Ships (Geneva, 12 March 1999, in force 14 September 2011; UNTS vol. 2801; Doc. A/CONF.188.6; C.N.112.2011. Article 7(1) (emphasis added). It may also be noted that this jurisdiction over ships' arrest applies irrespective of the location of the act or omission that gave rise to the claim.

28 Maritime Labour Convention (Geneva, 23 February 2006, in force 20 August 2013; (2006) 45 ILM 792); http://www.ilo.org/global/standards/maritime-labour-convention/lang--en/ index.htm. 
for port states to assume jurisdiction and apply their own laws, and that this trend may be on the increase.

\section{Interest, Authority and Power}

Assertions of jurisdiction are never merely technical. They are the legal mantle donned by claims of authority, power, and interest. Thus, they are eminently political, both in terms of their formulation and contestation. ${ }^{29} \mathrm{PSJ}$ is not very different. Regardless of the legal technicalities set out above, both in terms of permission and limitation, port states will usually tend to exercise jurisdiction when it is in their own interest, and when they are of the view that, given their political or economic power, they can get away with it.

Interest, or rather the absence of it, explains why there is hardly any practice regarding Article 218 LOSC, the Article that provides for extra-territorial jurisdiction over pollution discharges from vessels outside the port state's maritime zones. ${ }^{30}$ Precisely because this provision provides for the exercise of jurisdiction in the international rather than the national interest, states have not proved willing to commit precious national resources to institute proceedings from which others benefit-a classic prisoners' dilemma indeed. The risk that vessels will avoid their ports, resulting in economic harm to the port and its hinterland, serves as an additional disincentive to the vigorous exercise of PSJ. In the field of fisheries, it may seem that states accept the common interest somewhat more, and are willing to clamp down on IUU fishing via PSJ. In reality, however, the long-term sustainability of existing fish stocks, even on the high seas, is also in the interest of port states which have their own distantwater fishing fleets that may economically suffer from overfishing by their competitors. In this respect, it would be somewhat far-fetched to characterize such PSJ as a disinterested vindication of 'the global interest' or 'global values'. Chile's notorious closure of its ports to Spanish vessels fishing for swordfish on the high seas off its E EZ, ${ }^{31}$ and the EU's more recent closure of its ports to Faroe Islands-flagged vessels which had captured herring and mackerel in the North

\footnotetext{
29 A Kaushal, 'The Politics of Jurisdiction' (2015) 78(5) The Modern Law Review 759-792.

30 But see Directive 2005/35/EC of the European Parliament and of the Council of 7 September 2005 on ship-source pollution and on the introduction of penalties for infringements [2005] OJ L255/11, Article 6(1) which obliges EU Member States to implement Article 218(1) LOSC at least by means of an appropriate 'inspection' of a ship suspected of violations in the high seas. 
East Atlantic, ${ }^{32}$ are fine examples of such self-serving PSJ, even in relation to areas beyond national jurisdiction, such as the high seas.

PSJ is not only a function of interest-maximization, but, relatedly, also of power and capacity differentials. ${ }^{33}$ Even where port states have an undeniable interest in the exercise of PSJ, e.g., where a vessel's substandard shipping conditions threaten their own maritime zones, or where the depletion of fish stocks adversely affects its own fishing industry, a port state will typically only exercise jurisdiction when it can mobilize sufficient resources, ${ }^{34}$ and when it has the economic power to impose its will on foreign-flagged vessels and their state or regional backers. Ports with a developed enforcement machinery, and serving a sizable market, e.g., EU and Us ports, are much more likely to vigorously assert PSJ. Especially when this market is inelastic - when vessels have few alternatives to calling at the assertive port-PSJ will prove effective. Conversely, port states that have relatively little clout, even if they have enforcement capacity, may have to defer to more powerful states or regional organizations protecting their vessels over which the former states exercise PSJ. It could thus just happen that one and the same institutional actor advances arguments in favour of and against PSJ in largely similar factual scenarios. As Andrew Serdy discusses, in the Swordfish dispute the EU contested another state's exercise of PSJ with respect to high seas fisheries, whereas in its dispute with the Faeroes, it turned the tables and asserted its own PSJ with respect to high seas fisheries. Such apparent inconsistency can then only be explained by political power-play,

32 Atlanto-Scandian herring (n 24).

33 More generally, states use international law to further their own preferences. See for this rational choice approach to international law, e.g., AT Guzman, How International Law Works: A Rational Choice Theory (Oxford, Oxford University Press, 2008), at p. 17 ("States are assumed to be rational, self-interested, and able to identify and pursue their interests", implying that state preferences are fixed, exogenous to international law), and at p. 12 (arguing that "international law serves primarily to shape preferences and express the views of states or other actors").

34 This explains, for instance, why Article 25 (3)(c) of Part viI of the Agreement for the Implementation of the Provisions of the United Nations Convention on the Law of the Sea of 10 December 1982 relating to the Conservation and Management of Straddling Fish Stocks and Highly Migratory Fish Stocks (New York, 4 December 1995, in force 11 December 2001) 2167 UNTS 3, provides for capacity-building so as to assist developing states in assuming their role in the exercise of PSJ. It is of note, however, that also developing countries have been able to jointly harness the resources to successfully exercise PSJ. In her contribution, Judith Swan notably shows how several African countries, albeit supported by an international NGO, have shared information and cooperation, and on that basis managed to bring a halt to the criminal fishing activities of a South Koreanflagged vessel. 
which is in turn facilitated by vague formulations of normative concepts (such as 'unregulated fishing') and international standards.

In spite of its potential for inconsistency or even outright abuse, we would consider the existence of power differentials between port states as an empirical reality that is normatively neutral, i.e., not inherently bad or good. Having power may create opportunities to run roughshod over existing legal constraints, ${ }^{35}$ or to give self-serving interpretations to norms, especially where no external, 'objective' monitoring or judicial mechanism is available. However, a legal system such as the international one, that, not least in shipping, is characterized by compliance problems, an enforcement deficit accentuated by the lack of centralized institutions, and a relative failure to adequately supply global public goods, ${ }^{36}$ is also critically dependent on actors assuming their own institutional responsibilities in a decentralized fashion. Whereas their actions may perhaps most immediately be triggered by a desire to vindicate some aspect of 'the national interest', they may well, and may even be calculated to, have a beneficial impact on the common interest.

Thus, the concern that single-hull tankers will cause environmental damage in a coastal state's maritime zones has led some coastal/port states to require (or speed up the introduction of) double hulls. Such a requirement has an obvious effect on the marine environment also outside the state's maritime zones. Somewhat similarly, the concern that climate change will adversely affect the $\mathrm{EU}$, coupled with the concern that restricting EU environmental regulation to EU-based operators might economically disadvantage them vis-à-vis their foreign competitors, have informed the adoption of an $\mathrm{EU}$ monitoring, reporting, and verification (MRV) scheme with respect to the emissions of all vessels calling at EU ports "as the first step of a staged approach to reduce greenhouse gas emissions." ${ }^{37}$ Such a scheme, albeit only enforced in EU ports, has, given the nature of climate change, necessarily a global effect, which is strengthened by the requirement that it applies to emissions produced during the entire journey from a non-EU port to an EU port. These types of measure can be successful, and demonstrate that the use of PSJ by economically powerful and attractive port/market states can have a global beneficial impact. Sometimes such measures may also be deliberately aimed at pushing the envelope for

35 This appears to be the basic message of JL Goldsmith and EA Posner, The Limits of the Law (Oxford, Oxford University Press, 2007).

36 See (2012) 23(3) European Journal of International Law—special issue on global public goods. 
a multilateral regulatory solution along the lines of the unilateral measure. ${ }^{38}$ As argued, their orientation towards common concerns may have an important legitimizing effect, provided that the measure is properly designed (i.e., does not make arbitrary distinctions, and is not aimed at shielding the state's own industry) and may hence offer additional weight to the balancing of interests in relation to the (equally common) interest of ship operators to maintain uniformity in global regulation.

38 J Scott and L Rajamani, 'EU Climate Change Unilateralism' (2012) 23(2) European Journal of International Law 469-494. 